LA-8624-T

Thesis

UC.11

Issued: December 1980

\section{Measurements of Uranium in Soils and Small Mrmmals}

Felix Rafael Miera, Jr.

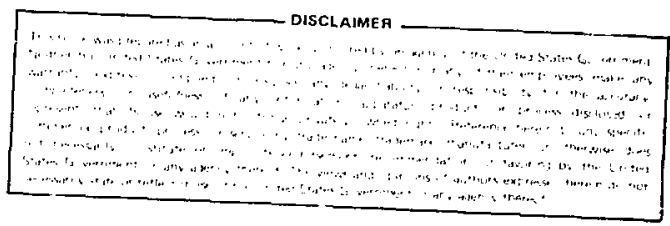




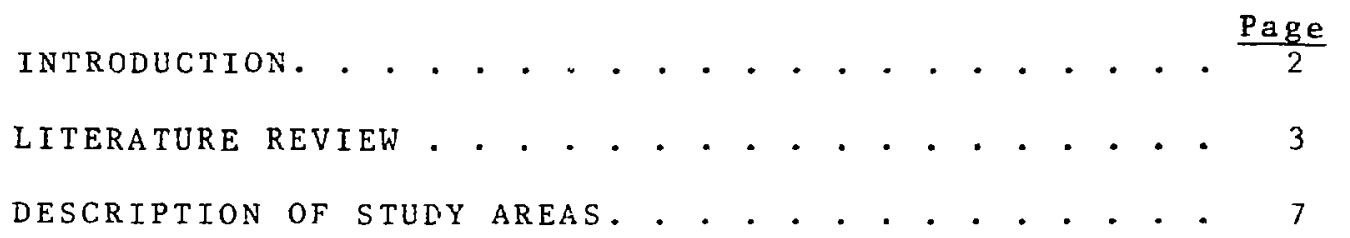

The LASL Study Area. . . . . . . . . . . . . 7

The Uranium Mill Tailings Study Area . . . . . . . 9 METHODS • . . . . . . . . . . . . . . . . . . 11

Sample Collection at the LASL E-F Site. . . . . 11

Sample Collection at the Uranium Mill. Tailings Site. . . . . . . . . . . . . . . 13

Sample Preparation... . . . . . . . . . . 16

Analyses of Samples for Uranium. . . . . . . . . 17

RESULTS AND DISCUSSION. . . . . . . . . . . . . . . . . . . 18

Distribution of Uranium in LASL Soils. . . . . . 18

Distribution of Uranium in Soils on the Perimeter

of the Phillips Mill Tailings Pile. . . . . . . 25

Uranium Concentrations in Tissues of Smal1

Mammals.................. . . 29

SUMMARY AND CONCLUSIONS . . . . . . . . . . . . . . 38

LITERATURE CITED. . . . . . . . . . . . . . . 4 41 


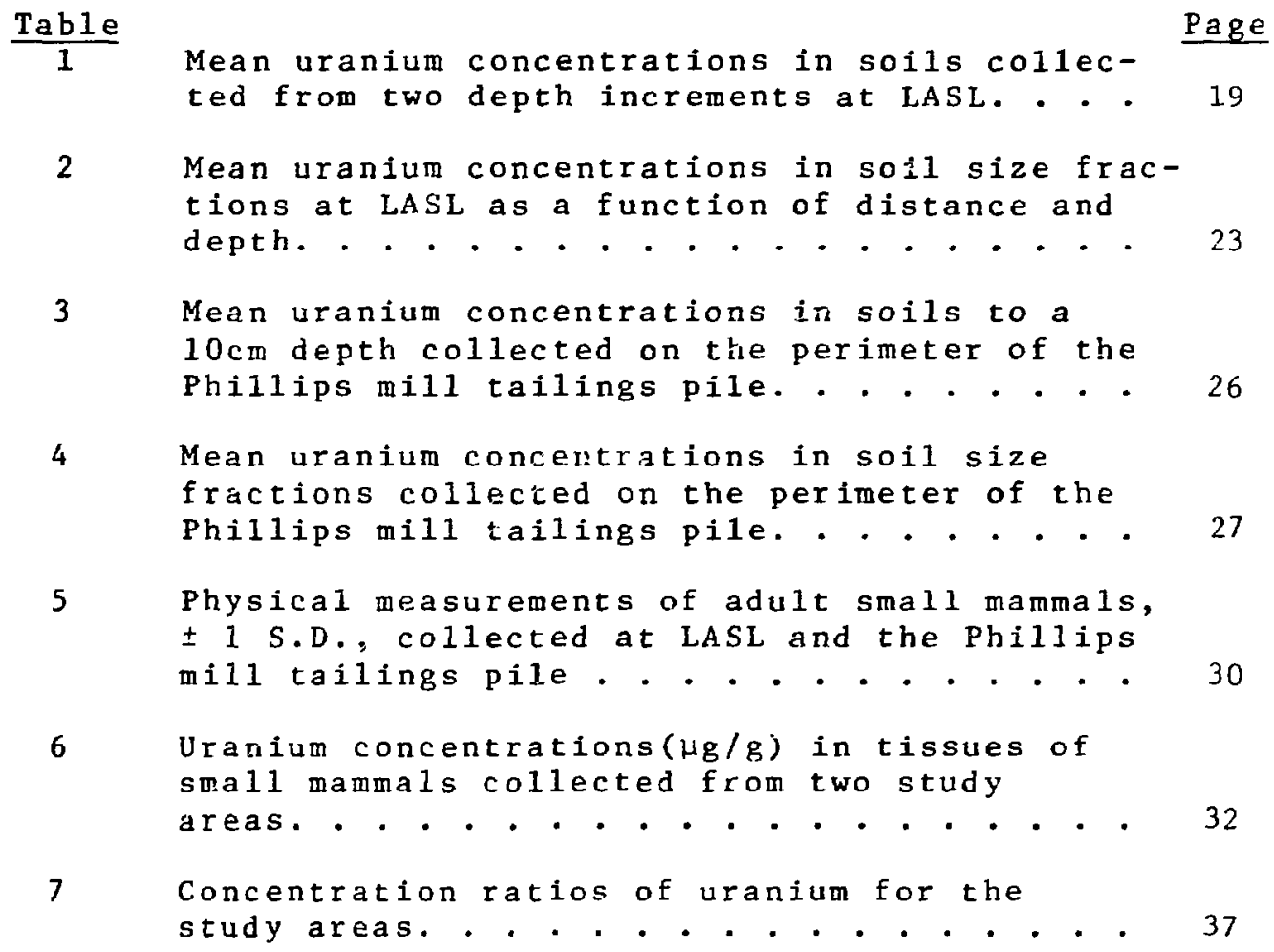




\section{LIST OF FIGURES}

$\frac{\text { Figure }}{1}$

Location of the Los Alamos Scientific

Laboratory in northcentral New Mexico. . . 8

2 Location of the Phillips uranium mill tailings pile.................. 10

3 Soil sampling and small mammal trapping locations at the LASL site....... . . . 12

4 Grid locations for small mamml trapping and soil sampling at the perimeter of the Phillips mill tailings pile............. 15

5 Calculated isopleths of uranium concentrations In the 0- to 5-cm soil horizon at the LASL site...................

6 The percent of the total uranium and percent soil mass associated with each size fraction as a function of soil depth and distance from the detonation point at the LASL site. The left-side bar for each size fraction is for the 0- to 5-cm depth and the right-side bar is for the 5-to 10-cm depth........ . 24

7 The percent of the total uranium and percent soil mass associated with each size fraction as a function of soil depth at the perimeter of the mill tailings pile. The left-side bar for each size fraction is for the 0-to 5-cm depth and the right-side bar is for the 5- to 10-cm depth. . . . . . . . . .

8 Distribution of uranium concentrations for GI and pelt samples from the LASL site in relation to the mean values. Both distributions are positively skewed. . . . . . . 34

9 Distribution of uranium concentrations for GI, pelt and kidney samples from the perimeter of the Phillips mill tailings pile in relation to the mean values. All three distributions are positively skewed. . . . . . . 
MEASUREMENTS OF URANIUM IN SOILS AND SMALL ANIMALS

\author{
by
}

Fel ix Rafael Miera, Jr.

\begin{abstract}
The objective of this study was to evaluate the bioavailability of uranium to a sirgle species of small mammal, Peromyscus maniculatus rufinus (Merriam), whitefooted deer mouse, from two different source terms: a Los Alamos National Laboratory dynamic weapons testing site in north central New Mexico, where an estimated $70000 \mathrm{~kg}$ of uranium have been expended over a 31-yr period; and an inactive uranium mill tailings pile located in west central New Mexico near Grants, which received wastes over a 5-yr period from the milling of $2.7 \times 10^{9} \mathrm{~kg}$ of uranium ore.
\end{abstract}




\section{INTRODUCTION}

With the increasing use of atomic energy for peaceful and military application the environmental problems associated with radioactive and toxic waste products which may be introduced into the environment must be anticipated. Nuclear power generation using uranium is presently being examined as a viable alternative to fossil fuel power plants. Military applications include the use of depleted urarium $\left({ }^{235} \mathrm{U} /{ }^{238} \mathrm{U}<0.0072\right)$ in conventional weapons tests and as armour-piercing projectiles. The need for appreciable production of uranium to feed these and other industries results in the generation of mill tailings piles which are left exposed to the natural environment. Despite the importance and ubiquitous nature of uranium, its ecological behavior in the environment is not well understood.

The objective of this study vas to evaluate the bioavailability of uranium to a single species of small mammal, Peromyscus maniculatus rufinus (Merriam), white footed deer mouse, from two different source terms: a Los Alamos Scientific Laboratory dynamic weapons testing site in north central New Mexico where an estimated $70,000 \mathrm{~kg}$ of uranium have been expended over a 31 year period; and, an inactive uranium mill tailings pile located in west central New Mexico near Grants which received wastes over a five year period from the milling of $2.7 \times 10^{9} \mathrm{~kg}$ of uranium ore.

In this study an attempt is made to determine if uranium concentrations in tissues and organs of Peromyscus can be related to soil uranium concentrations for the respective sites. Uranium concentrations were determined for various soil size fractions and whole, i.e. unfractionated soil samples, to assess uranium availability to Peromyscus through igestion or respiration of contaminated materials. 


\section{LITERATURE REVIEW}

Uranium is an ubiquitous constituent of our natural environment. With the introduction of nuclear weapons during World War II an intensive effort was initiated to characterize uranium poisoning and to determine relative toxicities of the various uranium compounds for establishing human health standards in the industry (Yuile, 1973). Decay characteristics for isotopes of uranium with mass numbers 227 through 240 have been reported (Gindler, 1973); of these, only the isotopes ${ }^{235} \mathrm{U}$ and ${ }^{238} \mathrm{U}$ have half-lives sufficiently long $\left(7.1 \times 10^{8}\right.$ and $4.49 \times 10^{9}$ years, respectively) to be found as primordial substances in nature.

Most natural uranium ores contain 0.1 to $2 \%$ uranium $\left(\mathrm{U}_{3} \mathrm{O}_{8}\right)$ with relative abundances of ${ }^{235} \mathrm{U}$ and ${ }^{238} \mathrm{U}$ of $0.72 \%$ and $99.27 \%$, respectively. Milling processes remove about $90 \%$ of the total uranium, with the remainder released in the tailings (Tsivoglou and $0^{\prime}$ Connel, 1964). Depleted uranium, a by-product resulting from the ${ }^{235} \mathrm{U}$ enrichment process, contains about 0.2 wt\% ${ }^{235} \mathrm{U}$ and the remainder is composed of ${ }^{238} \mathrm{U}$. Differences in natural and depleted uranium thus result from a departure of the crustal abundance isotopic ratio: ${ }^{235} \mathrm{U} /{ }^{23}{ }^{8} \mathrm{U}<0.0072$.

Environmental studies in areas of high natural radioactivity (Cannon, 1952; Mericle and Mericle, 1965; Cullen and Franca, 1977) and uranium mill waste investigations (Anderson et al., 1963; Dreesen, 1978), have for the most part been concerned with radiation effects of nuclides other than uranium and other nonradioactive contaminants. The primary processing removes most of the ${ }^{238} U$ decay chain products that are of major concern for depleted uranium. Principal concern for the isotopes ${ }^{235} \mathrm{U}$ and ${ }^{238} \mathrm{U}$ is their chemical toxicity; the alpha particle emissions from these nuclides have very low penetrability 
in $\operatorname{air}(\approx 3 \mathrm{~cm})$.

The geological distribution of uranium ore bodies has been studied in much detail, and is reported throughout the literature. However, a recent review of the 1iterature (Hanson, 1974) indicates a limited number of indepth studies describing the distribution and fate of uranium contaminants in the environment. The chemical and physical parameters which govern the mobility of uranium are known to be influenced by such parameters as clay content, organic matter content and soil acidity. The natural uranium content of surface waters in the U.S. averages $5 \times 10^{-4} \mu \mathrm{U} / 1$, although this value is highly variable, and is influenced by factors such as the geological formations in which waters arise and flow through and the size and diversity of their watersheds (Koc 2y, 1963).

In terrestrial ecosystems studies in uranium-vanadium deposits of the Colorado Plateau showed the following responses of vegetative species to their chemical environment: uranium absorption, anomolous growth habits, and the development of a particular flora or indicator species (Canon, 1952). For plants rooted in uranium bearing rock highest concentrations are usually found in roots and seeds. Uranium concentrations ranged from 2 to $100 \mathrm{ppm}$, compared to values of generally less than $1 \mathrm{ppm}$ for species from outside this area. Availability of uranium to plants is strongly influenced by soil clay content, organic matter content, soil acidity and depth of the root system. Cannon (1952) reported concentration factors (plant uranium concentration $\div$ soil uranium concentration) for shale derived soils of 0.09 to 0.9 and 0.007 to 0.01 in sandstone soils for a wide variety of plants. Morphological effects in plants from high uranium areas resulting from radiation induced genetic change include double 
flowering, leaf splitting and corolla colar variation (Kovalsky et al., 1967).

Investigations of small mamals which permanently inhabit regions of high natural radioactivity have again mostly emphasized radiation effects. Important pathways for potential exposure and biological uptake include: (1) close contact with the soil layer in their burrows and above ground activities; (2) inhalation of resuspended soil particles and gaseous products, as from radon gas; (3) ingestion of contaminated food materials, both vegetation and invertebrates, or soil particles which are attached to the animals pelt and ingested during grooming activities.

In intensive studies of areas with high natural taidoactivity in the U.S.S.R. (Maslov et al., 1967) several bio:ogical effects were attributed to the increased radiation levels. Morphological and physiological changes were observed in the germinal epithelium of the gonads, tissues of the spleen, bone marrow, liver cornea and other organs. Exposure levels in the study area ranged from 5000-8000 $\mu R / h r$. The authors concluded that over the several generations of exposure the population as a whole was affected resulting in a decrease in vitality and fecundity of the population.

However, to gain an understanding of the effects attributable solely to uranium, one must rely on the results obtained in controlled laboratory experiments. Based on the results of extensive experimentation, it is generally concluded that the degree of acute uranium poisoning depends on the amount initially absorbed and the consequent level in the bloodstream, irrespective of the route of administration. Critical pathways for the uptake of uranium pertinent to this study are ingestion of uranium contaminated materials and inhalation of respirable size 
particles to which uranium may be adsorbed.

In short-term (30 day) feeding experiments with rats, uranium compounds which are relatively insoluble in water, such as $\mathrm{U}_{3} \mathrm{O}_{8}, \mathrm{UO}_{2}$, and UF, were fed in diets containing up to $20 \%$ of these substances and were found to be non-toxic and showed little if any interference with growth. Also, no significant histopathological changes were detected. However, $100 \%$ mortality resulted from diets which contained 2 to $10 \%$ uranium compounds which are highly water soluble, such as $\mathrm{UO}_{2} \mathrm{AC}_{2}, \mathrm{UCl}_{4}, \mathrm{UO}_{2} \mathrm{~F}_{2}, \mathrm{UO}_{2}\left(\mathrm{NO}_{3}\right)_{2} \cdot 6 \mathrm{H}_{2} \mathrm{O}, \mathrm{UO}_{3}$ and $\mathrm{UO}_{4}$. Diets containing 0.1 to $1.0 \%$ of the water solubie compounds resulted in growth depression (Yuile, 1973). Renal effects were also detected in this group, with extent of damage and frequency of occurrence dependent on the compound and dosage.

In oral ingestion experiments with durations of 1 to 2 years, the relative toxicity of uranium compounds was obtained by comparing the dietary percentages required to produce equal body weight depressions: $\mathrm{UO}_{2} \mathrm{~F}_{2}, 0.25 \% ; \mathrm{UO}_{2}\left(\mathrm{NO}_{3}\right)_{2}, 1 \% ; \mathrm{UF}_{4}, 20 \% ; \mathrm{UO}_{2}$, at $20 \%$ showed no influence on growth (Voegtlin and Hodge, 1953). Rats maintalned on a $2 \%$ uranyl nitrate diet showed moderately severe initial injury followed by regeneration and progressive atrophic changes in the renal tubules, as well as some degenerative changes in the testes. Uranium analyses of the kidneys and femurs receiving these four uranium compounds showed that only slight increases of uranium were detected for the insoluble compounds with significant increases for the soluble uranium compounds. After cessation of ingestion, uranium in the bone was found to mobilize and be excreted from the body.

Regarding toxicity following inhalation, the solubility of uranium compounds was again a significant in producing efiects. Particle 
size is also as inportant parameter, with residence time in the lungs generally increasing as particle size decreases. The sequence of events in uranium poisoning following inhalation is similar to other routes of uranium administration and is dependent on maximum levels in the blood stream attained at any given time by solubilization and absorption of uranium.

\section{DESCRIPTION OF STUDY AREAS}

The LASL Study Area

The Los Alamos Scientific Laboratory consists of $113 \mathrm{~km}^{2}$ in northcentral New Mexico on the Pajarito Plateau, which is situated on the eastern slopes of the Jemez Mountains west of the Rio Grande (Fig. 1). The plateau, which has a pronounced elevational gradient in the eastwest direction, was formed by successive ash flows from a volcanic area $32 \mathrm{~km}$ to the west. The soils of the area have just recently been characterized in detail (Nyhan et al., 1978). The climate is semiarid, with approximately $46 \mathrm{~cm}$ of annual precipitation. Nearly $75 \%$ of this occurs during spectacular May-October thundershowers and accounts for much of the canyon erosion.

E-F testing site, situated on a mesa top at $2190 \mathrm{~m}$ elevation, is located in the western central portion of LASL and has had the most continuous use history for the expenditure of uranium at LASL, beginning in mid-1943. An estimated $65,000-75,000 \mathrm{~kg}$ of natural and depleted uranium have been expended at this site in conventional explosives tests over a 30-year period from 1943 to 1973. Reportedly, no cleanup operations have occurred to date due to the lack of known or suspectej hazardous conditions. Thus, it is assumed that the uranius inventory is available for uptake and transfer through the food chain, or for surface transport, mainly by storm runoff in the adjacent Potrillo Canyon drainage. 


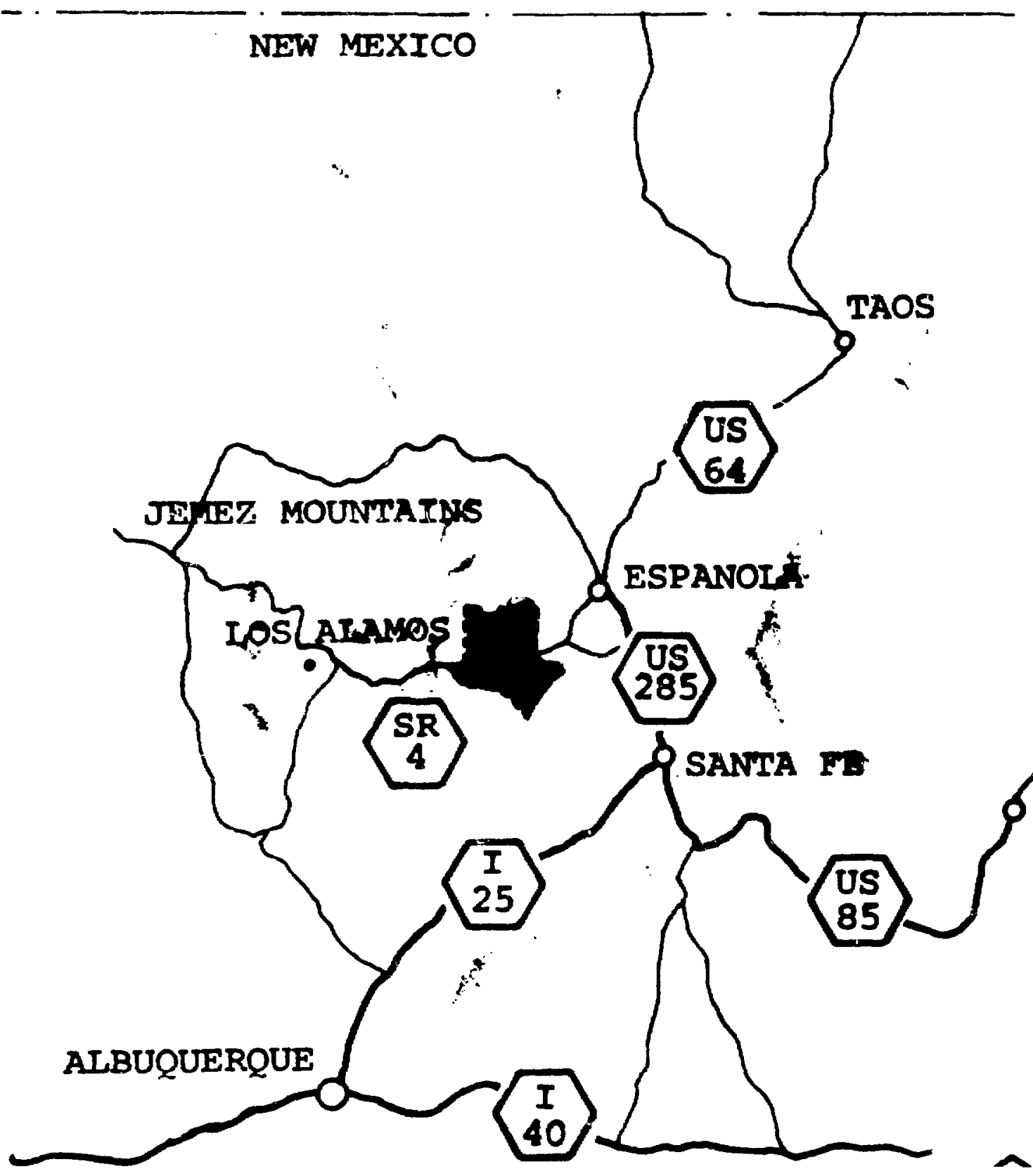

Fig. 1. Location of the Los Alamos Scientific Laboratory in northcentral New Mexico. 
The LASL study site exhibits evidences of both uranium's pyrophoric properties and/or resultant explosive properties, in that the overstory vegetation surrounding the site has been burned and is in successional recovery stages. The understory vegetative cover consists mostly of three Invader species, Kochia scoparia (Belvedere sumer-cypress), Salasola kali (Russian thistle), and Sitanion hystrix (bottlebrush squirreltail). Dominant overstory vegetation found on the outer perimeter of the study site includes Pinus pondersoa (ponderosa pine), Pinus edulis (pinon pine), and Juniperus monosperma (one-seed juniper).

The Uranium Mill Tailings Study Area

The Phillips Petroleum tailings pile is located approximately $40 \mathrm{~km}$ north of the southern extension of the San Juan Basin in the Ambrosia Lake mining district in nnrthwestern New Mexico (Fig. 3). Mount Taylor is the prominent extrusion in the area, located approximately $20 \mathrm{~km}$ to the southeast of the study area. Major drainage through the Ambrosia Lake area is the southeastern trending Arroyo del Puerto, which has perennial flow resulting from mining and milling processes in the area and is a tributary of San Mateo Creek. Annual precipitation averages about $25 \mathrm{~cm}$. The tailings for the Phillips Petroleut pile were produced from milling about $2.7 \times 10^{9} \mathrm{~kg}$ of uranium ore from 1958 to 1963 . The estimated volume of tailings was reported in 1977 to be about $1.5 \times 10^{6} \mathrm{~m}^{3}$, ranging in thickness from 1 to $10 \mathrm{~m}$ (Purtymun et. a1., 1977). The uranium was extracted from the ores using a carbonate leaching process, the waste separated from the leach solution and pumped to the pile as a slurry. A series of dikes were built surrounding the pile to contain the tailings. No vegetative species have successfully adapted to the pile, apparently a result of the chemical harshness of the environment. Transport of mill tailings from the pile to adjacent areas is via wind erosion and 


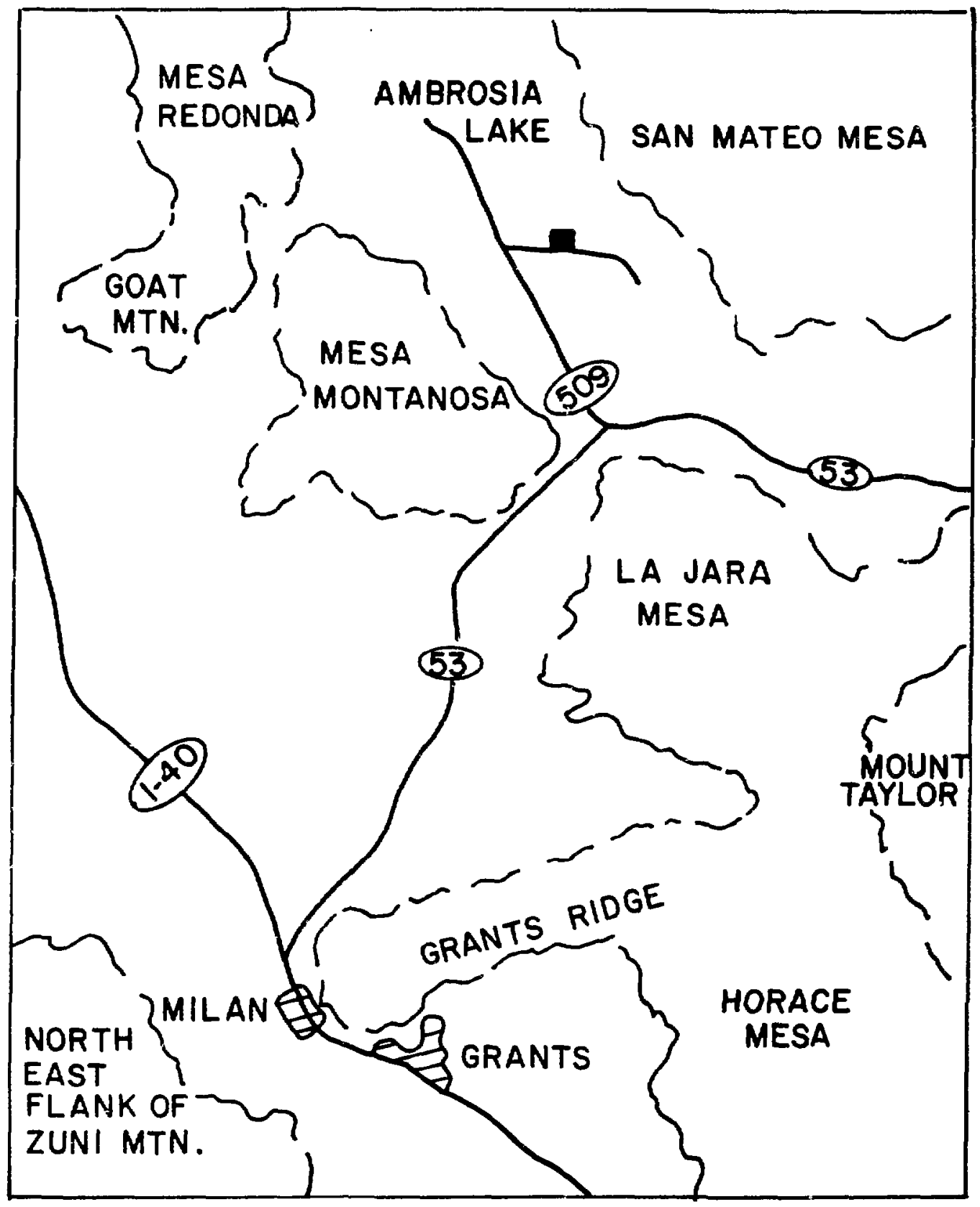

PHILLIPS PETROLEUM TAILINGS PILE

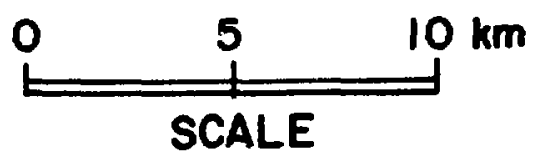

Fig. 2. Location of the Phillips uranium mill tailings pile. 
surface water transport.

The outer periphery of the pile where study areas were located, evidences disturbed habitat with lush growths of invader vegetative species, primarily Sitanion hystrix, Salsola kali, and Kochia scoparia. Native vegetation in the vicinity of the tailings pile is that typically found in a short-grass plains area, dominated by Boutelous gracilis (blue grama) and Hilaria Jamesii (galleta grass).

\section{METHODS}

\section{Sample Collection at E-F Site}

A polar coordinate sampling scheme was devised for intensive investigation of the vertical and horizontal soil distribution of uranium at shis site for a separate study (Miere et al., 1978). Soil cores were collected at the intersection of radii that extended from the detonation point at each $45^{\circ}$ azimuth and concentric circles 10, 20, 30, $40,50,100,150$, and 200 in from the detonation poini (Fig. 3). A polyvinylchloride coring tube $(2.5 \mathrm{ctn}$ i.d.) with a sharpened end was used to collect two $30-\mathrm{cm}$ deep soil cores spaced $0.5 \mathrm{~m}$ apart at each sampling location.

One core from each location was cut into segments corresponding to 0 - to 5- and 5- to 10-cm to examine depth distribution patterns. Thirty percent of the duplicate cores collected from the NE, SE, SW, and NW quadrants were randomly selected, and similarly processed, to define the spatial variability of uranium with distance from the detonation point and with depth into the soil profile.

Forty soil samples representing duplicate $0-$ to $5-\mathrm{cm}$ and $5-$ to $10-\mathrm{cm}$ depth cores collected from the N. F, S, and W quadrants at distances of 10, 20, 50, 100, 150, and $200 \mathrm{~m}$ from the detonation point were processed for soil particle size analysis. These samples were mechanically separated by means of a sonic sifter into six size fractions. 


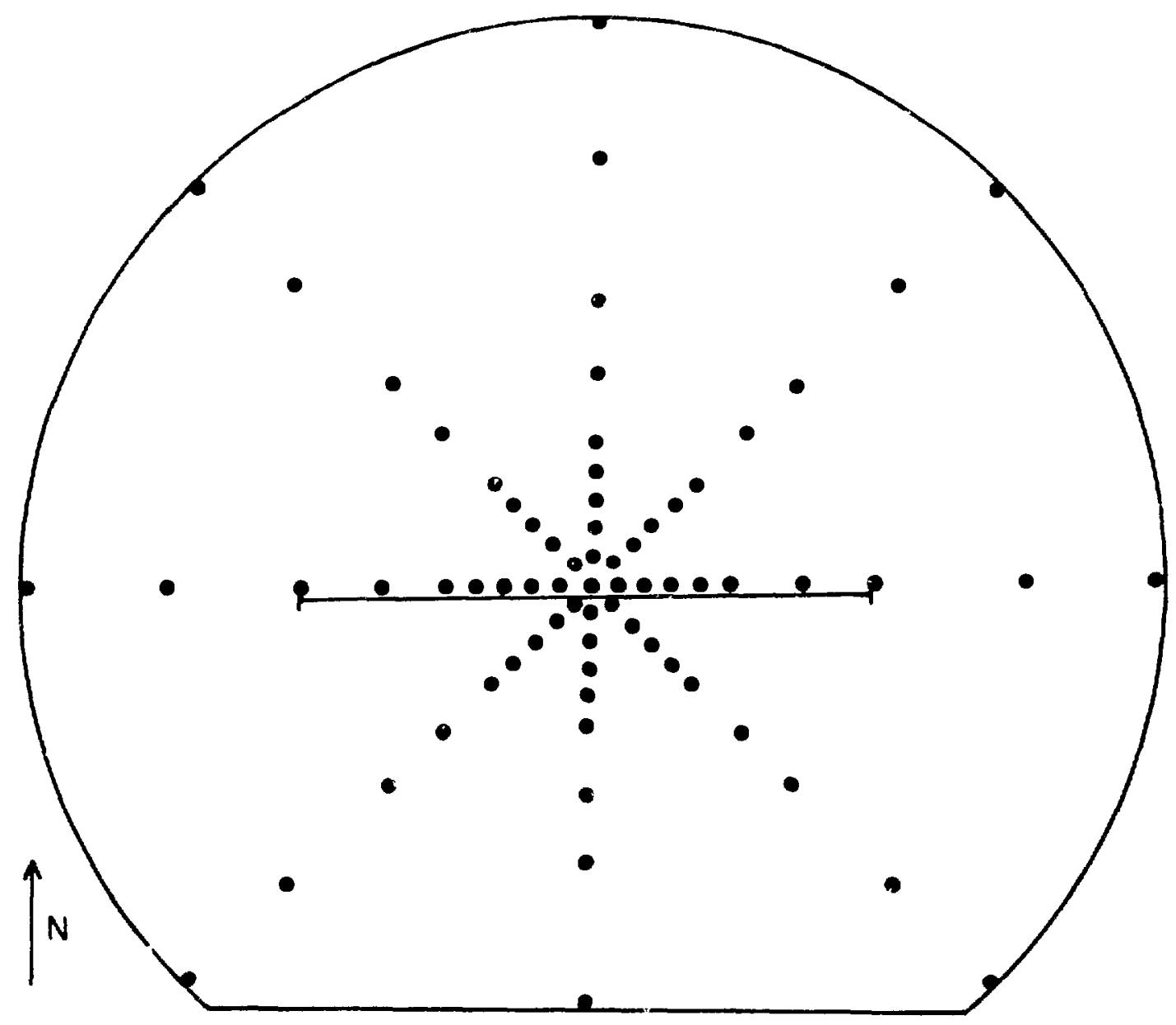

- soil sampling locations

$\longmapsto$ SMALL MAMMAL TRAPPING LINE

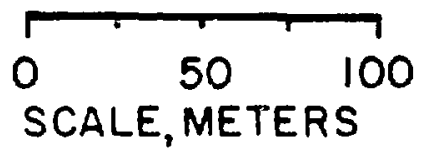

Fig. 3. Soil sampling and small mammal trapping locations at the LASL site. 
Modified North American Census of Small Mammals (NACSM) trapping Iines (Calhoun, 1948) were permanently marked for collection of Peromyscus during April, 1977. Two trap lines were established at the site parallel to each other and the earthen mounds that bracket the detonation point. Each line was $190 \mathrm{~m}$ long and consisted of 20 stations at 10-m intervals. Three snap traps baited with peanut butter were placed within I m of each station in positions that appeared most likely to catch small mammals. The traps were prebaited for two nights, followed by three consecutive nights of trapping.

Data recorded on all animals included capture location, species identification, sex, age class, reproductive condition, and weight. The micure then packaged individually and frozen pending dissection. Measurements of each specimen at dissection included lengths of total body, tail, ear, and hind foot.

Trap line positions were determined by approximated fallout pathways of particulate material from the firing site. Thus, the distance between the parallel trap lines was less than that used for standard NACSM estimates of home ranges and populations. The size of area sampled for rodent populations was determined using the method of Brandt (1962). This method utilizes the average distance between successive points of capture. As snap traps were used for this study, a value of $52.4 \mathrm{~m}$ for Peromyscus was also obtained from the data of Brandt, assuming that habitats were not significantly different for these calculations. This value was determined as an average for both sexes during five trapping periods on a grid. Treating the $33 \mathrm{~m}$ distance between the parallel trap lines as an overlapping range, the area sampled was determined to be 4.1 hectares. Sample Collection at the Uranium Mill Tailings Site

Soil and small mammal samples were taken from the north, east, and 
south sides, on the outer periphery but adjacent to the tailings pile (Fig. 4). An intensive survey of urasium in the soils at this site could not be undertaken, because the total number of chemical analyses that could be performed was limited. A random sampling pattern was used for th" purposes of determining concentration patterns of uranium, spatial variability distribution of uranium to a depth of $10 \mathrm{~cm}$, and distribution of uranium associated with various soil particle size fractions.

Trapping lines similar to those described previously, were permanently marked on each of the three sides of the pile. Four random soil sampling plots were located at stations $2,8,10$, and 15 . Additional soil sampling plots were located at a $10 \mathrm{~m}$ distance on each side of and perpendicular to the sampling points located on the trap lines.

At each $\mathrm{cf}$ the soil sampling points, a $1 \mathrm{~m}^{2}$ plot was marked of $f$ and all standing vegetation removed to ground level. Two soil samples were collected on the diagonal from the NW and SE corn $r S$ of the $1 \mathrm{~m}^{2}$ plots, in $10 \times 10 \times 5 \mathrm{~cm}$ incremerts at 0 - to 5- and 5- to 10-cm depths. Samples taken from the NW corners of each plot located on the center trap lines were used for analysis of soil particle size distributions.

Two trapping sessions were required to collect sufficient numbers of micr for analyses. For the first session in July 1977 single modified NACSM trapping lines were established parallel to each of the three sides of the pile. Low capture success resulting from inclement weather necessitated a second trapping session in early August 1977 . In an effort to increase trapping success, two additional trap lines were established, on each side of and parallel to the original lines. Distance between the parallel lines was limited to $10 \mathrm{~m}$ by access and ore haulage roads parallel with the south and east sides of the pile. Three snap traps baited with peanut butter were placed within a $1 \mathrm{~m}$ radius of each trapping station. 


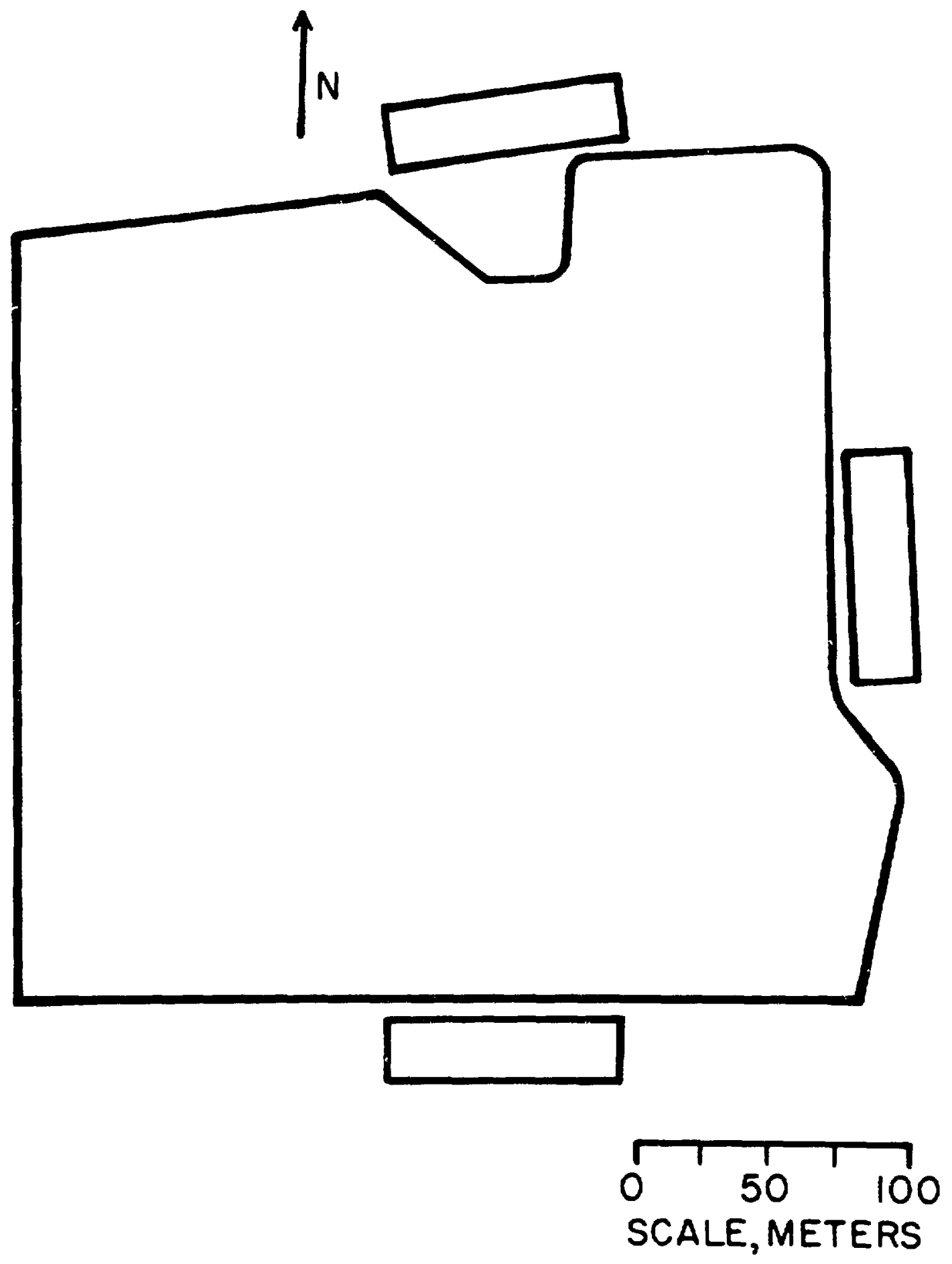

Fig. 4. Grid locations for small mammal trapping and soil sampling at the perimeter of the Phillips mill tailings pile. 
Both trapping sessions consisted of two nights of prebaiting, followed by three consecutive nights of trapping and collections. Similar data was recorded for all individuals as described for E-F Site specimens.

Since most Peromyscus captures were in the second trapping session, the size of area sampied was determined by considering the three lines as a partial grid. The area sampled on each side of the pile was 0.8 hectares, determined by calculating the area of a rectangle with dimensions of $200 \mathrm{~m}$ by $40 \mathrm{~m}$.

\section{Sample Preparation}

All soil samples collected were oven-dried at $100^{\circ} \mathrm{C}$ to a constant dry weight $(\approx 24 \mathrm{hrs.}$ ) and the dry weight recorded. The samples were then passed through a 6-mm screen to remove large pie. ss of rock, roots, and other debris. With the exception of those samples to be used for particle size analyses, all whole samples were ground to less than 100 mesh in a pulverizer and thoroughly blended to provide a honogenous sample. A 3- to 4-gm aliquot of each blended sample was submitted for uranium analyses, with replicate aliquots submitted for approximately fifteen percent of the total samples.

Scil samples collected for particle size analyses were mechanically separated into six size fractions by means of a sonic sifter to: $<53 \mathrm{\mu m}$, 53-105 $\mu \mathrm{m}, 105-500 \mu \mathrm{m}, 500-1000 \mu \mathrm{m}, 1-2 \mathrm{~mm}$, and 2-23 diameters. Small soil particles were blown from the larger soil separates with an air hose after sifting to minimize contamination of the large particles. The particle diameters may be further described according to US Department of Agriculture Soil Conservation Service standard soil size categories as fol.lows: 
Particle Diameter ( $\mu \mathrm{m})$

$<53$

53-105

$105-500$

$500-1000$

$1000-2000$

$2000-23000$
Size Fraction

silt and clay

Very fine sand

Medium and fine sand

Coarse sand

Very coarse sand

Coarse fragments

All rodents were carefully dissected to minimize cross-contamination of internal organs and tissues by soil particles adhering to the fur. Tissues and organs analyzed separately included the pelt, carcass (skelton and skeletal muscles), lungs, GI (gastrointestinal) contents, liver, and kidneys. To increase sample mass and uranium analytical detection sensitivity, deer micr samples were pooled by pairing according to capture location and sex. Rodent samples were oven-dried at $100^{\circ} \mathrm{C}$ for $24 \mathrm{hrs}$, or until a constant dry we.ght was recorded, and then muffled at $450^{\circ} \mathrm{C}$ until a white ash was obtained. The entire ashed sample was submitted for analyses.

\section{Analyses of Samples for Uranium}

Two analytical techniques were used in the analysis of samples for uranium in this study. The delayed neutron assay technique was user for all samples collected in the Grants area. This technique operates on the principle of a fixed uranium isotopic ratio $\left({ }^{235} \mathrm{U} /{ }^{238} \mathrm{U}\right)$ because ${ }^{238} \mathrm{U}$ does not fission with thermal neutrons. As the ratio departs from 0.0672 , as with depleted uranium, large errors in determination of total uranium can be made. Thus samples from the LASL area were done by instrumental epithermal neutron activation analysis (IENAA), which is insensitive to ${ }^{235} \mathrm{U}$ (Steinnes, 1971; Gladney et al., 1978).

Delayed neutron measurements were performed by irradiating the sample 
for 20 seconds in a thermal neutron flux. The sample was pneumatically transferred to a neutron detector of $27 \%$ efficiency and counted for 20 seconds looking at emissions of about 6 short lived decay products. The uranium concentrations were calculated assuming natural lootopic abundance of ${ }^{235} \mathrm{U}$.

Samples analyzed by the IENAA technique were irradiated with epithermal. neutrons for two minutes with the reaction ${ }^{238} \mathrm{U}(n, \gamma){ }^{239} \mathrm{U}, \boldsymbol{B}$ $2{ }^{39} \mathrm{~Np} \stackrel{\beta, \gamma}{2}{ }^{39} \mathrm{Pu}$. After 2 to 4 days decay, the gamma spectra of the 228 and $278 \mathrm{keV}$ transitions from the decay of ${ }^{239} \mathrm{~Np}\left(t_{1 / 2}=2.35 \mathrm{~d}\right)$ were determined on a large $G e(L i)$ detector and used for quantitative analysis. Several standard reference soil, plant and tissue materials (International Atomic Energy Agency and National Bureau of Standards) with certified concentrations over the range of expected uranium results were used to standardize all analysis.

\section{RESULTS AND DISCUSSION}

\section{Distribution of Uranium in LASL Soils}

Highest mean concentrations for the $0-$ to $5-\mathrm{cm}$ sampling depth at the LASL site were found within $10 \mathrm{~m}$ of the detonation point, averaging 4750 and $4910 \mathrm{jg} \mathrm{U} / \mathrm{g}$ at 0 and $10 \mathrm{~m}$ respectively. Uranium concentrations in surface soils decreased exponetially with distance from the detonation point and distances beyond $50 \mathrm{~m}$ from the firing point were generally less than $15 \%$ of the se taken within $10 \mathrm{~m}$ (Table I). Surface soil uranium concentrations varied greatly, and presumably were strongly influenced by the variable deposition of uranium debris in the form of fragments from past explosive tests. The Coefficient of Variation/(CV=standard deviation/mean) $x$ 100) for solls collected $0.5 \mathrm{~m}$ apart at individual sampling locations ranged from 18 to $96 \%$, averaging $57 \%$ for all distances. For samples collected along individual annuli i.e., sampling locations at the sume distance CVs 
Table 1. Uranium concentrations in solls collected from two depth increments at LASL.

\begin{tabular}{ccc} 
& & $0-5 \mathrm{~cm}$ Depth \\
& Number & Mean \\
Distance & of & Uranium \\
(m) & Samples & $(1 \mathrm{~g} / \mathrm{g})$ \\
\hline 0 & 2 & 4750 \\
10 & 8 & 4910 \\
20 & 6 & 835 \\
30 & 8 & 1330 \\
40 & 7 & 710 \\
50 & 8 & 475 \\
100 & 8 & 370 \\
150 & 8 & 730 \\
200 & 7 & 165 \\
A11 Soils & 62 & 1340
\end{tabular}

\begin{tabular}{rr} 
Number \\
of \\
C..$^{a}$ & Samples \\
\hline 64 & 2 \\
100 & 6 \\
68 & 4 \\
84 & 6 \\
36 & 6 \\
59 & 7 \\
91 & 4 \\
231 & 2 \\
91 & 2 \\
& 39
\end{tabular}

$5-10 \mathrm{~cm}$ Depth

Mean

Urantum

Concentration

$\begin{array}{cc}(\mu \mathrm{g} / \mathrm{g}) & \text { C.V. } \\ 3800 & 33 \\ 3950 & 99 \\ 190 & 66 \\ 640 & 66 \\ 470 & 62 \\ 570 & 94 \\ 165 & 50 \\ 40 & 61 \\ 18 & 58\end{array}$

${ }^{a}$ Coefficient of Variation 
averaged 36 to $100 \%$ within $100 \mathrm{~m}$ of the detonation point but increased to as high as $230 \%$ at $150 \mathrm{~m}$ distances.

Uranium concentration isopleths shown in Figure 5 demonstrate the hetrogeneity of uranium dispersal resulting from the test shots. Isopleths were obtained by transforming each data point to log values, and then converting the polar coordinate sampling array values to Cartesian coordinate values. The plane surface was generated by a program which interpolated between data points. From the isopleths, areas of highest soil concentrations were detected at the detonation point and $150 \mathrm{~m}$ to the west with uranium levels $>3000 \mu g / g$ soil. Surface soils to the south and northeast of the detonation point also exhibited high uranium concentrations ranging from 300 to $1000 \mathrm{\mu g} / \mathrm{g}$ of soil.

Samples taken at the 5- to $10-\mathrm{cm}$ depth within 10 m of the detonation point were only slightly lower than surface values observed for these same sampling locations. For sampling locations at $20 \mathrm{~m}$ and beyond, differences between the $0-$ to $5-\mathrm{cm}$ and $5-$ to $10-\mathrm{cm}$ depths, mean uranium concentrations ranged from factors of 2 to 18 times less, with one exception at $50 \mathrm{~m}$. However, the large variations associated with observed values (Table 1) again indicate the strong influence of uranium dispersal patterns from explosive test shots. Mean concentrations of 165 and $18 \mu \mathrm{gU} / \mathrm{g}$ at 100 and $200 \mathrm{~m}$ sampling locations are about 80 and 10 times greater, respectively, than background uranium levels in soils for the area which range from 0.2-1.2 $\mu \mathrm{g} / \mathrm{g}$ (Johnson, 1972). These data emphasize uraniun's mobility in the soil and also that uranium has penetrated to greater depths than sampled.

To evaluate the potential for redistribution of uranium which might be adsorbed to soil particles by physical or biological means, the particle size composition and uranium content of soil separates were 


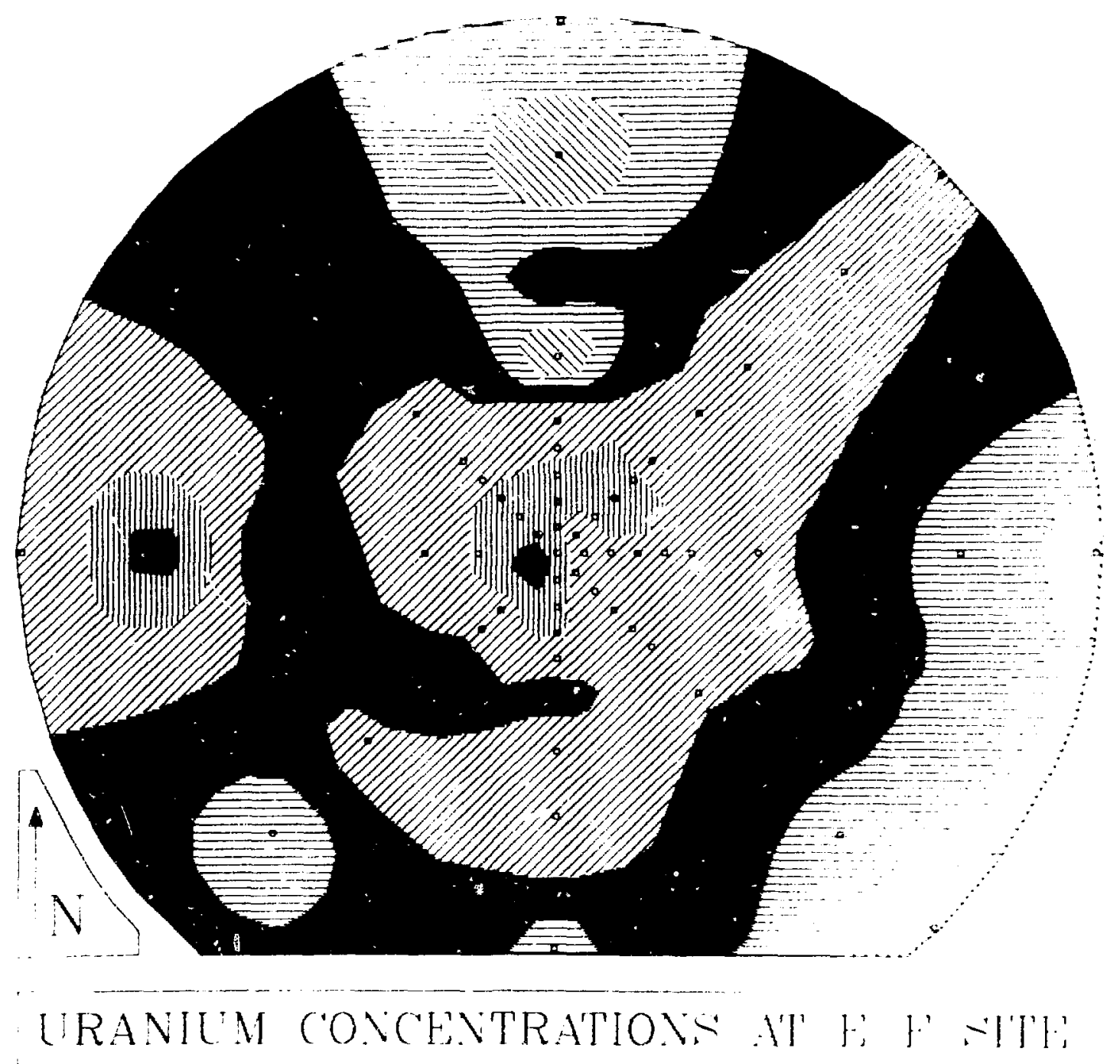

ISOPLETHA: $05 \mathrm{~cm}$ HORIZON

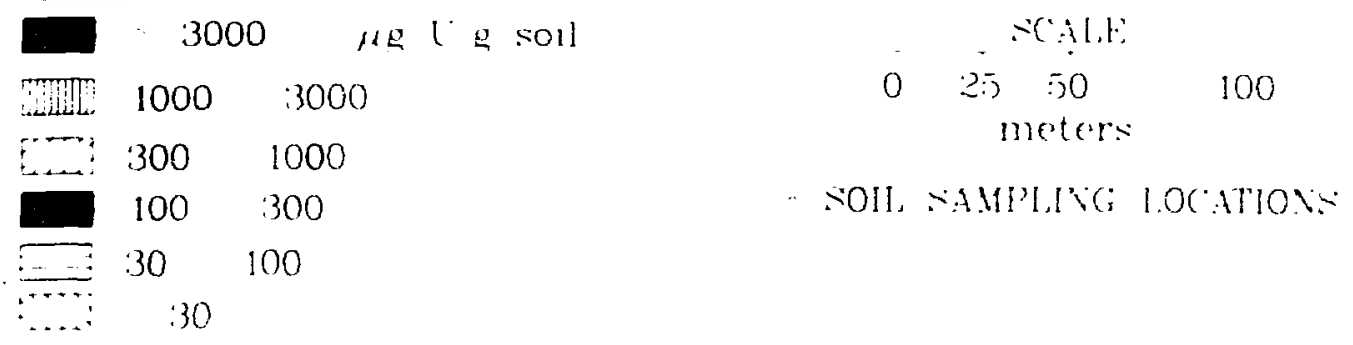

Fig. 5. Calculated isopieths of $\mathbf{u}_{\perp}$ anium concentrations in the $0-$ to $5-\mathrm{cm}$ soil horizon at the LASL site. 
determined. Uranfum concentrations in six soil size separates from the 0 - to 5-crm and 5- to 10-cm depths are presented in Table 2. Generally, an exponential decrease of uranium concentration with distance was observed for each size fraction, although with appreclable variation noted in values as a function of both distance from the detonation point and depth in the soil profile. Highest concentrations of uranium were found at the $10 \mathrm{~m}$ distance in the $<53 \mu \mathrm{m}$ size fraction for both soil column increments; however, at $20 \mathrm{~m}$ to $50 \mathrm{~m}$ distances the highest concentrations were generally associated with the larger particle sizes (1-2 $\mathrm{mm})$. For sampling locations $100-$ to $200-\mathrm{m}$ from the detonation point the highest concentrations were again associated with the smaller soil particle sizes $(<500 \mu m)$.

The fractional distribution of uranium in the soil separates was also determined. The portion of the total uranium in each size fraction was calculated by multiplying the concentration by the soil mass of each fraction. The distribution of uranium for all sampling locations in the six soil size fractions for the $0-$ to $5-$ and $5-$ to $10-\mathrm{cm}$ depths indicated that about $70 \%$ of the total uranium and $60 \%$ of the soil mass were associated with $<500 \mu \pi$ soil particles (Fig. 6). For the $0-$ to $5-\mathrm{cm}$ depth, the percent uranium associated with the $<500 \mu m$ size fractions increased from $50 \%$ at the $10 \mathrm{~m}$ sampling locations to nearly $90 \%$ at the $200 \mathrm{~m}$ sampling locations. Soil masses for the respective sampling locations in the <500um fractions (classified as silt, clay, and sand fractions) were 40 and $70 \%$. The ratio of the total uranium in the $<53 \mu \mathrm{m}$ fraction to that in the $2-23 \mathrm{~mm}$ fraction for the 0-5- and 5-10-cm depths increased from 1.1 and 2.5 at $10 \mathrm{~m}$ to 18 and 21 at the $200 \mathrm{~m}$ sampling locations, respectively. These distribution patterns suggest that mobilization and physical transport, i.e., surface water and wind, of uranium associated with smaller soil particles 
Table 2. Mean uranium concentrations in soil size fractions at LASL as a function of distance and depth.

\begin{tabular}{|c|c|c|c|c|c|c|c|c|}
\hline $\begin{array}{l}\text { Distance } \\
\text { (m) }\end{array}$ & $\begin{array}{l}\text { Soil } \\
\text { Depth } \\
\text { (cm) } \\
\end{array}$ & $\begin{array}{l}\text { Number } \\
\text { of } \\
\text { Samples }\end{array}$ & $\leq 53 \mu \mathrm{m}$ & $53-105 \mu \mathrm{m}$ & $\begin{array}{l}(\mu \mathrm{g} / \mathrm{g}) \text { in } \mathrm{s} \\
105-500 \mu \mathrm{m}\end{array}$ & $\begin{array}{l}\text { seperates } \\
500-1000 \mu \mathrm{m}\end{array}$ & $1-2 \mathrm{~mm}$ & $>2 \mathrm{~mm}$ \\
\hline \multirow[t]{2}{*}{10} & $0-5$ & 4 & 7280 & 2050 & 3500 & 2830 & 2940 & 2430 \\
\hline & $5-10$ & 4 & 5130 & 2450 & 2690 & 1870 & 1720 & 1150 \\
\hline \multirow[t]{2}{*}{20} & $0-5$ & 3 & 1260 & 820 & 1030 & 595 & 1700 & 1290 \\
\hline & $5-10$ & 3 & 360 & 350 & 450 & 380 & 900 & 145 \\
\hline \multirow[t]{2}{*}{50} & $0-5$ & 5 & 795 & 900 & 900 & 530 & 750 & 205 \\
\hline & $5-10$ & 5 & 425 & 950 & 510 & 420 & 300 & 200 \\
\hline \multirow[t]{2}{*}{100} & $0-5$ & 4 & 240 & 430 & 410 & 285 & 720 & 120 \\
\hline & $5-10$ & 4 & 170 & 205 & 230 & 210 & 160 & 8 \\
\hline \multirow[t]{2}{*}{150} & $0-j$ & 2 & 80 & 110 & 130 & 50 & 14 & 17 \\
\hline & $5-10$ & 2 & 31 & 80 & 55 & 27 & 12 & 33 \\
\hline \multirow[t]{2}{*}{200} & $0-5$ & 2 & 170 & 250 & 310 & 115 & 20 & 29 \\
\hline & $5-10$ & 2 & 29 & 27 & 19 & 20 & 7 & 4 \\
\hline
\end{tabular}



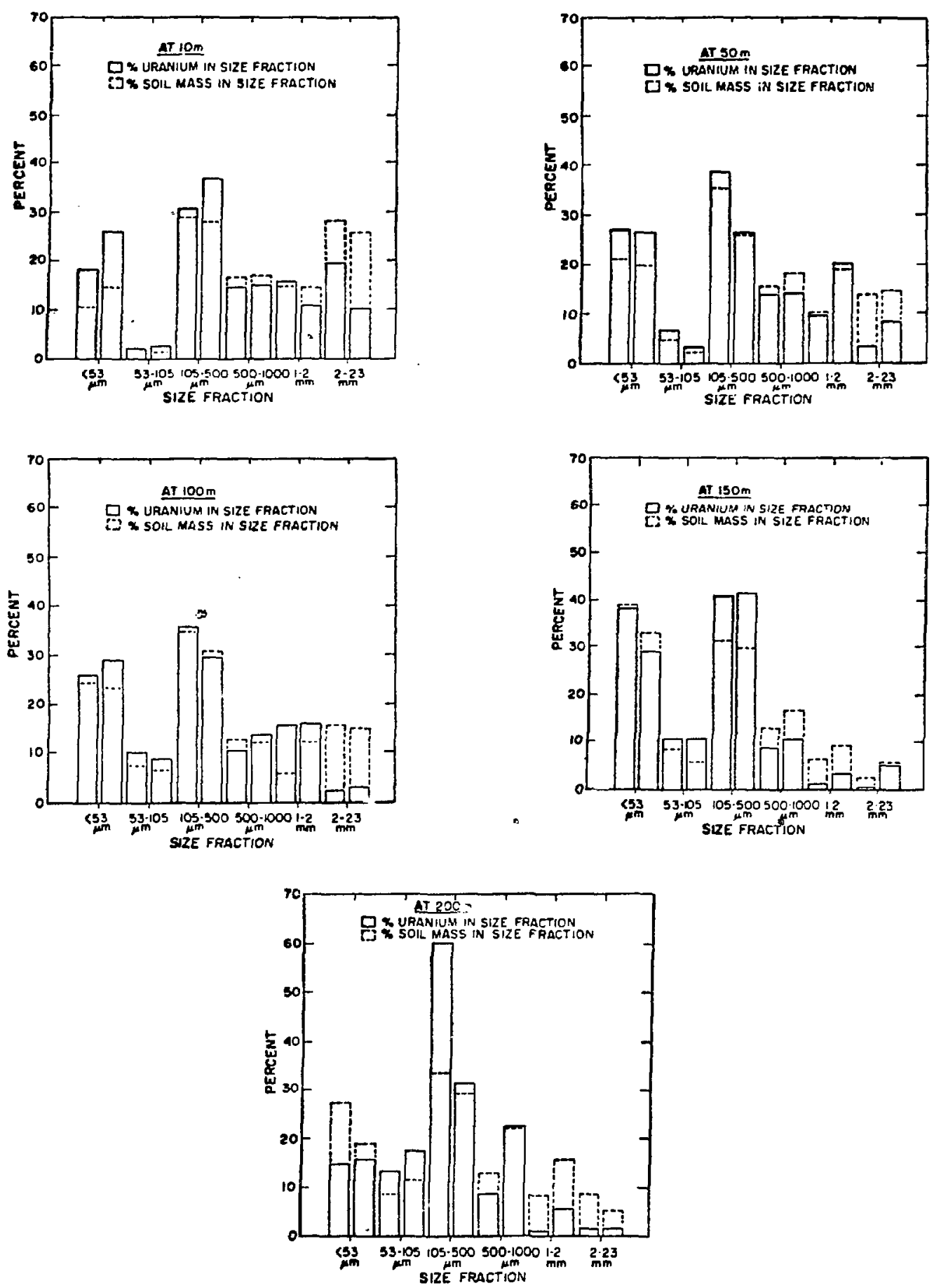

Fig. 6. The percent of the total uranium and percent soil mass associated with each side fraction as a function of soil depth and distance from the detonation point at the LASL site. The left-side bar for each size fraction is for the 0 - to $5-\mathrm{cm}$ depth and the right-side bar is for the $5-$ to $10-\mathrm{cm}$ depth. 
is occurring with time at this site.

Distribution of Uranium in Soils at the Perimeter of the Phillips

Mill Tailings Pile

The highest mean uranium concentrations detected for whole soil samples collected at the perimeter of the Phillips mill tailings pile were about fifty times less than those observed at the detonation point of LASL's E F site; five and four times less than average values at 50 and $100 \mathrm{~m}$, respect.vely; and within the range of values for samples collected at the 200 m distance. Highest mean uranium values were detected on the east side of tho pile averaging $86 \pm 28$ (1 S.D.) $\mu \mathrm{gU} / \mathrm{g}$ soil in the top $5 \mathrm{~cm}$ and $103 \pm 32 \mu \mathrm{gU} / \mathrm{g}$ in the lower $5 \mathrm{~cm}$ of soil. Mean values for both iepth increments sampled on each of the three sites are presented in Table 3. Coefficient of variation values of less than $50 \%$ were measured for all sample groupings with the exception of the $0-5 \mathrm{~cm}$ depth on the north side, compared to $\mathrm{CV}^{\prime} \mathrm{s}$ which ranged up to four times higher in the LASL soils. For samples taken across the diagonal in each $1 \mathrm{~m}^{2} \mathrm{plot}$, the east and south transects generally had $\mathrm{CV}$ values of less t inan $20 \%$. However, samples taken on the north transect reflected high spatial variability, with some samples having almost identical concentrations, and others ranging as high as $100 \%$ in variation.

The particle size composition and uranium content of soil separates was determined for the north and east transects as previously described. The results of this exercise are shown in Table 4 and Fig. 7 . Over $90 \%$ of the suil mass consisted of particles $<500 \mu \mathrm{m}$ in size, with the greatest portion in one size catagory, the 105 to $500 \mu \mathrm{m}$ fraction. This trend was observed for both depths sampled and for both transects. The importanca of this parameter is that particles less than $500 \mathrm{Hm}$ in size are those whi.h are generally associated with wind and water erosion. Again, over $90 \%$ 
Table 3. Mean uranium concentrations in soils to a $10 \mathrm{~cm}$ depth collected on the perimeter oi the Phillips mill tailings pile.

\begin{tabular}{|c|c|c|c|c|c|c|}
\hline \multirow[b]{2}{*}{ Transect } & \multicolumn{2}{|c|}{$\underline{0-5 \mathrm{~cm} \text { Depth }}$} & \multicolumn{4}{|c|}{$5-10 \mathrm{~cm}$ Depth } \\
\hline & $\begin{array}{c}\text { Number } \\
\text { of } \\
\text { Samples }\end{array}$ & $\begin{array}{c}\text { Mean } \\
\text { Uranium } \\
\text { Concentration } \\
(\mu \mathrm{g} / \mathrm{g}) \\
\end{array}$ & C.v. ${ }^{a}$ & $\begin{array}{l}\text { Number } \\
\text { of } \\
\text { Samples }\end{array}$ & $\begin{array}{c}\text { Mean } \\
\text { Uranium } \\
\text { Concentration } \\
(\mu \mathrm{g} / \mathrm{g}) \\
\end{array}$ & C.V. \\
\hline North & 12 & 58 & 68 & 11 & 70 & 48 \\
\hline East & 12 & 86 & 33 & 12 & 105 & 31 \\
\hline Siuth & 8 & 44 & 26 & 8 & 38 & 27 \\
\hline All Soils & 32 & 65 & & 31 & 74 & \\
\hline
\end{tabular}

\footnotetext{
${ }^{a}$ Coefficient of Variation $=$ standard deviation $/$ mean $\times 100$.
} 
Table 4. Mean uranium concentrations in soil size fractions collected on the perimeter of the Phillips mill tailings pile.

\begin{tabular}{|c|c|c|c|c|c|c|c|c|}
\hline & $\begin{array}{l}\text { Soil } \\
\text { Depth } \\
\text { (cm) } \\
\end{array}$ & $\begin{array}{c}\text { Number } \\
\text { of } \\
\text { Samples }\end{array}$ & $\leq 53 \mu \mathrm{m}$ & 53-105 $\mathrm{\mu m}$ & $105-500 \mu \mathrm{m}$ & $500-1000 \mu \mathrm{m}$ & $1-2 \mathrm{~mm}$ & $>2 \mathrm{~mm}$ \\
\hline North & $0-5$ & 8 & 125 & 82 & 94 & 215 & 82 & 150 \\
\hline Transect & $5-10$ & 8 & 180 & 120 & 87 & 335 & 95 & 95 \\
\hline East & $0-5$ & 8 & 110 & 79 & 56 & 120 & 115 & N.D. ${ }^{a}$ \\
\hline ransect & $5-10$ & 6 & 110 & 80 & 68 & 85 & N.D. & N.D. \\
\hline
\end{tabular}

${ }^{a}$ No data resulting Erom a lack of soil particles in this size fractions. 


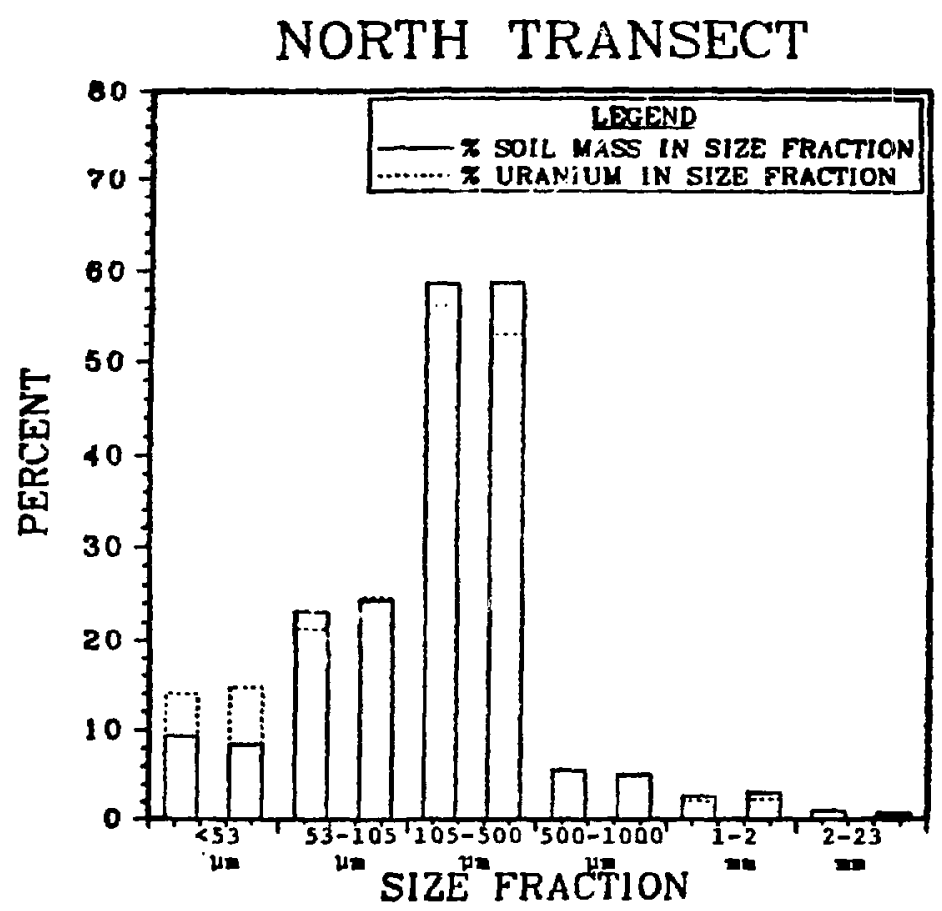

EAST TRANSECT

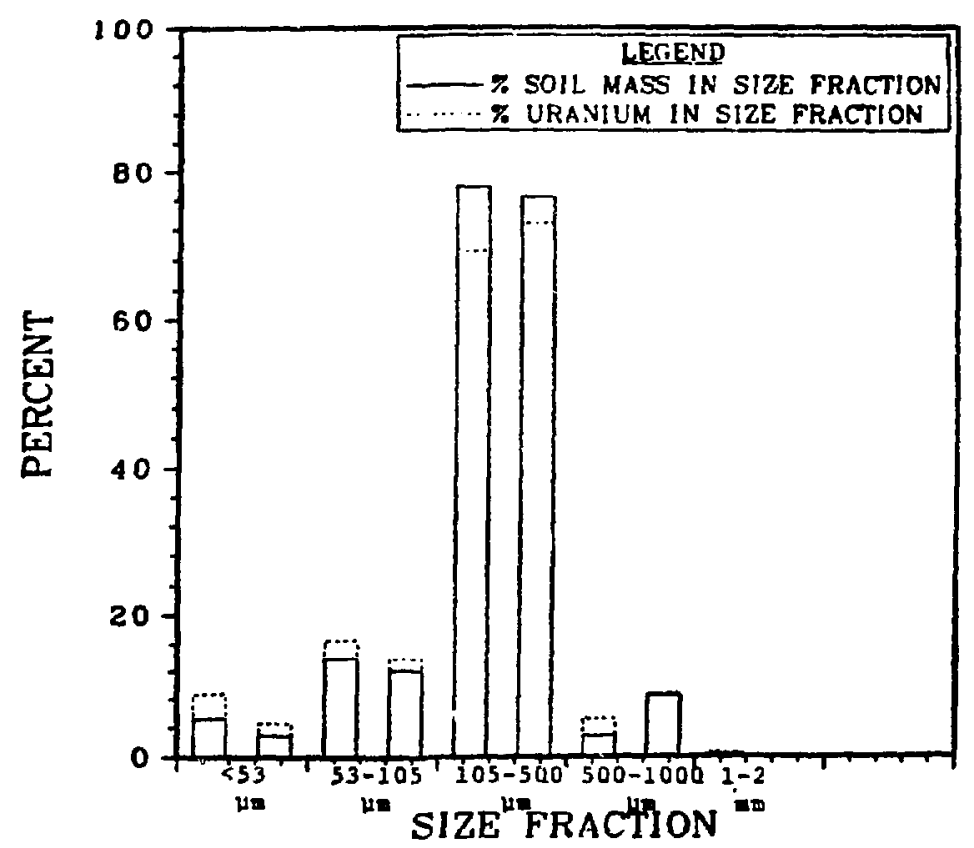

Fig. 7. The percent of the total uranium and percent soil mass associated with each size fraction as a function of soil depth at the perimeter of the mill tailings pile. The left-side bar for each size fraction is for the 0 - to $5-\mathrm{cm}$ depth and the right-side bar is for the 5- to 10-cm depth. 
of the uranium inventory for both transects and depths measured was associated with soil particles less than $500 \mu$ m in size and closely paralleled the particle size distributions. These results also indicate that vertical migration of uranium has occured and that the distribution of uranium to depths sampled was relatively homogenous.

The relatively homogeneous distribution of uranium in these soils is most probably controlled by two mechanisms. First, solubility of uranium at this site resulting from the refining process. As a consequence any precipitation or resulting runoff would distribute the uranium more evenl; through the soil matrix. Higher mean concentrations for the lower depth samples on the north and east transects, also supports the hypothesis of a soluble and mobile form of uranium. Second, the uniformity of soil particle sizes in which the uranium is dispersed, as vertical and horfzontal mixing of soils is related to particle size composition.

Uranium Concentrations in Tissues of Small Mammals

Trapping efforts for the two study areas yielded twenty and nineteen individuals captured at the LASL and mill tailings study areas, respectively. Mean measurements of selected physical characteristics by sex are listed in Table 5, and are similar for populations of both sites. The means recorded are within the range reported for this species (Hall and Nelson, 1959). The higher mean weight for females from the mill tailings area was attributed to three individuals whici were pregnant. Based on the size of area sampled minimal density estimates of Peromyscus for the areas sampled were 5 individuals/hectare at the LASL site and 8 individuals/hectare at the mill tailings study site. Uranium concentrations detected in tissues and organs of small mamals for the LASL and mill tailings study area are 1 isted in Table 6 , 
Table 5. Physical Measurements of Adult Small Mammals, \pm 1 S.D., Collected LASL and the Phillips mill tailings pile.

\section{LASL \\ E-F Site}

Males

Females

\section{Phtllips}

Mill Tailings

Pile

\section{Males}

Females

\begin{tabular}{cl}
$\begin{array}{l}\text { Number } \\
\text { of }\end{array}$ & $\begin{array}{l}\text { Mean } \\
\text { Weight } \\
\text { Samples }\end{array}$ \\
\hline
\end{tabular}

11

9

8

11
$20.3 \pm 2.2$

$19.3 \pm 4.9$

$18.3 \pm 2.4$

$22.8 \pm 5.4$
Total

Length

$(\mathrm{mm})$

$147 \pm 5$

$144 \pm 9$
Tail

Length

(mm)

$59 \pm 5$

$58 \pm 6$

$60 \pm 3$

$60 \pm 2$
Hind Foot

Length

(mm)

$18 \pm 2$

$18 \pm 2$

$18 \pm 2$

$16 \pm 2$

$143 \div 8$

$18 \pm 2$
Ear

He Ight

(mm)

$17 \pm 2$

$17 \pm 3$
$17 \pm 1$ 
with both the mean and medium values reported. For interpretation of these data tissues are grouped as to samples which have the potential for direct exposure to the external environment, i.e. the pelt, GI contents and lungs, and those tissues which have no contact with external uranium sources and included the kidney, liver and carcass (bone and skeletal muscle tissues). Although uranium concentrations were generally higher in all tissue groupings for LASL samples, comparisons of these values with various soil parameters investigated and uranium source terms provided interesting interpretations of the data.

Mean uranium concentrations for composite male plus female values indicates a significant difference in concentrations between tissue types. At both sites GI contents and pelt samples had the highest mean concentrations, all within the range of values reported for soils at each site. The remaining four tissues sampled at the LASL site decreased rapidly in mean concentrations, all ranging from 8 to $16 \mathrm{hgU} / \mathrm{g}$ sample compared to values of about 2000 and $500 \mathrm{HgU} / \mathrm{g}$ sample for GI and pelt samples, respectively. The low values obtained for lung tissues indicates that inhalation of respirable size particles was not occurring appreciably during the period of time that trapping was conducted. Again the hetrogeneity of uranium dispersal in soils as well as the effects of the mobility of Peromyscus are reflected by the range of minimum to maximum values and $\mathrm{CV}^{\prime} \mathrm{s}$ of $100 \%$ to $230 \%$ recorded for all tissue groupings.

Tissues from Peromyscus composites sampled in the vicinity of the mill tailings area showed similar results for tissue groupings with GI and pelt samples having the highest mean concentrations of 235 and $155 \mathrm{HgU} / \mathrm{g}$ of sample, respectively. Carcass, lung and liver tissues had essentially identical means of about $4 \mu \mathrm{gU} / \mathrm{g}$ (Table 6). One 
Table 6. Uranium concentrations $(\mu \mathrm{gU} / \mathrm{g}$ ) in tissues of small mamals collected from two study areas.

\begin{tabular}{|c|c|c|c|c|c|c|}
\hline LASL & $\underline{\bar{x}}$ & Median & c.v. ${ }^{\mathrm{a}}$ & Max. & Min. & $\underline{\mathrm{N}}^{\mathrm{b}}$ \\
\hline GI & 1985 & 880 & 1.22 & 8100 & 143 & 11 \\
\hline Pelt & 510 & 350 & 0.95 & 1530 & 102 & 11 \\
\hline Kidney & 16 & 19 & 1.19 & 60 & N.D. ${ }^{c}$ & 11 \\
\hline Carcass & 10 & 9 & 1.06 & 30 & N.D. & 11 \\
\hline Lung & 8.2 & 24 & 2.32 & 62 & N.D. & 11 \\
\hline Liver & 16 & 19 & 1.19 & 60 & N.D. & 11 \\
\hline
\end{tabular}

Mill Tailings

Pile

GI

$\begin{array}{rccccc}235 & 170 & 0.79 & 590 & 62 & 9 \\ 155 & 91 & 0.90 & 430 & 40 & 9 \\ 47 & 29 & 0.91 & 130 & 4 & 9 \\ 4.6 & 4.4 & 0.35 & 7 & 1.8 & 9 \\ 4.5 & 5.4 & 0.67 & 8.4 & 1.3 & 9 \\ 4.1 & 2.2 & 1.24 & 17 & 0.5 & 9\end{array}$

${ }^{a}$ Coefficient of variation $=$ standard deviation $/$ mean

${ }^{b}$ Number of samples

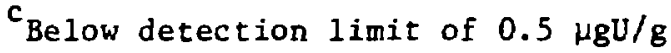


significant difference was the higher value detected for kidneys, $47 \mathrm{\mu gU} / \mathrm{g}$, which also supports the hypotheses of a more soluble form of uranium at this site. The kidneys in their physiological function of acting as a filtering medium for body fluids are recognized as the critical organ in reference to uranium (ICRP, 1969). As was observed in the review of the literature for experimental data with mice, oral feedings of water soluble uranium compounds also increased the uranium content of kidneys, whereas this was not found for insoluble uranium compounds. The range of values for all conjosite tissue groupings at this site was not as great as that observed for LASL samples. This is reflected by CV's of less than $100 \%$, with the exception of liver tissues. pooling of samples to enhance analytical sensitivity precluded any meaningful comparisons between sexes at the respective sites. However, inconcl sive results obtained for this study indicate differences of uranium concentrations between sexes, to be a topic which. . warrant further investigation. The value in pooling to increase sample mass is reflected by some minimum values obtainad for the LASL site, which even Lhrough this exercise were below detection levels of $0.5 \mathrm{HgU} / \mathrm{g}$ sample.

Figures 8 and 9 are plots of uranium concentration for samples ranked from the lowest to the highest values detected for tissues which had the largest uranium values. As stated previously, the concentration distributions for these samples is very large, with the distribution positively skewed, i.e. most values occur below the mean. Thus, for these tissues with high uranium concentrations the mean value is biased towards the larger values with the median values (Table 6) probably providing a more realistic estimate.

To test for equality of distribution of uranium concentrations in 


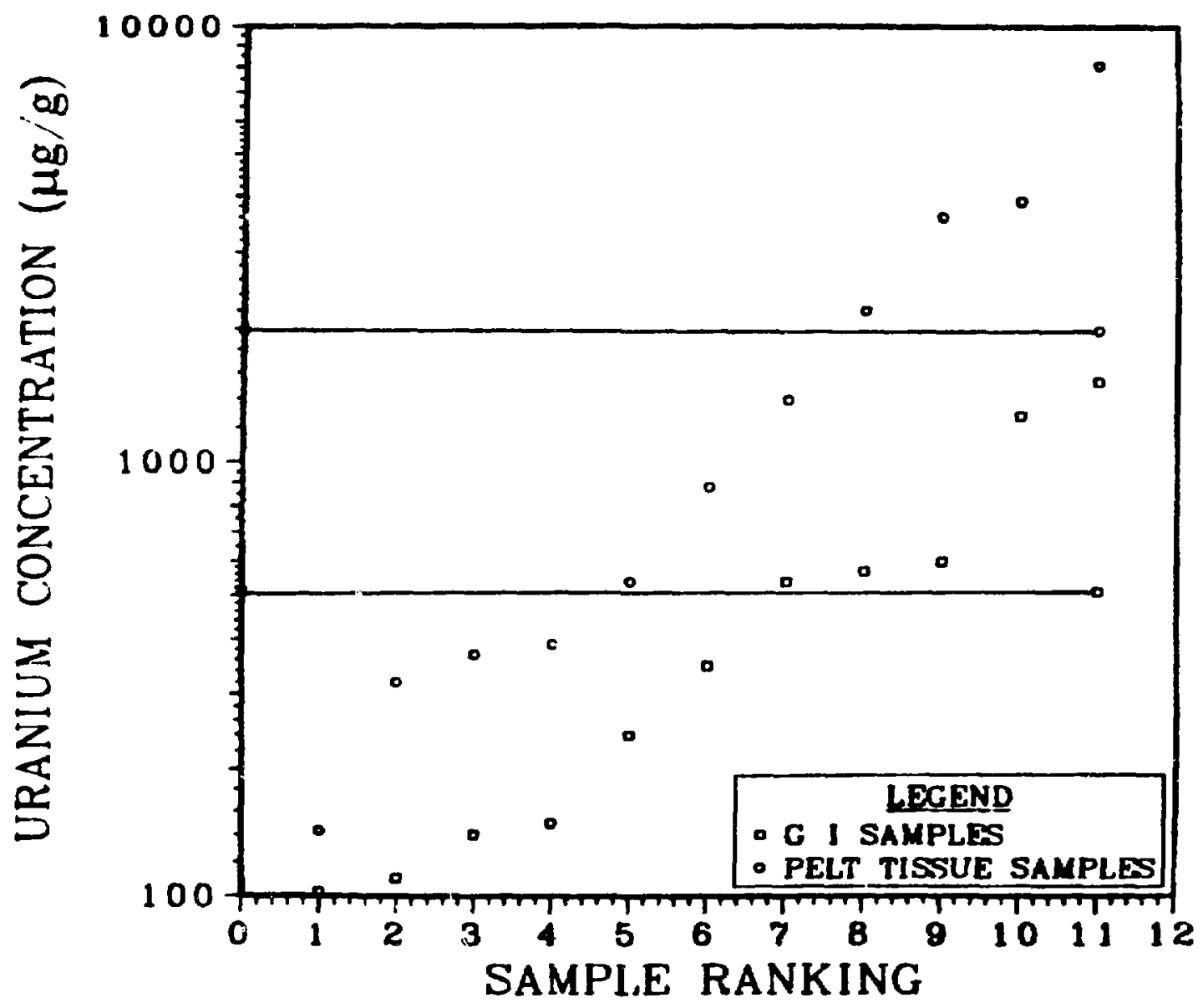

Fig. 8. Distribution of uranium concentrations for GI and pelt samples from the LASL site in relation to the mean values. Both distributions are positively skewed. 


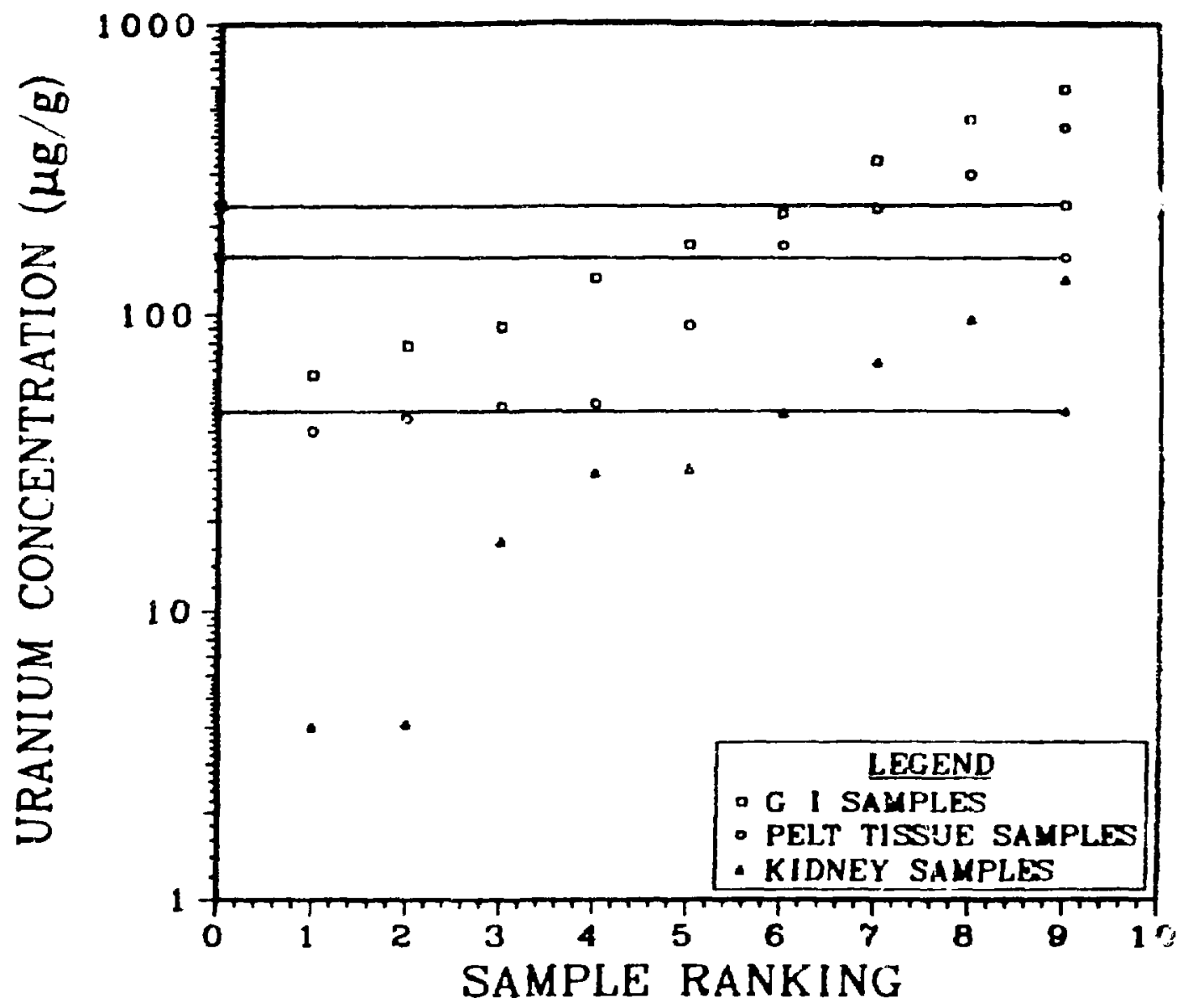

Fig. 9. Distribution of uranium concentrations for GI, pelt, and kidney samples from the perimeter of the Phillips mill tailings pile in relation to the mean values. All three distributions are positively skewed. 
small mammal tissues, a non-parametric method, the Mann-Whitney test, (Snedecor and Cochran, 1967) was used. For this statistical technique both groups to be tested are arranged in a single array and assigned a rank. The smaller sum of ranks is then referred to a table to determine significance. Results of this excercise showed differences between study areas for pelt samples, GI samples and kidney samples $(P \leq 0.05)$. For tissue concentrations within the mill tailings study area, GI versus kidney and pelt versus kidney were significantly different, and kidney concentrations were significantly different than carcass, lung and liver tissues $(P \leq 0.05)$. For tissues from the LASL site, GI and pelt values were significantly different than the remainder of $t j:$ sues $(P \leq U .05)$. Observed concentration ratios (CR) of animal tissue uranium to soil uranium are presented in Table 7 and were calculated using both the mean and median tissue values. The soil value used was that of the $0-5 \mathrm{~cm}$ horizon. The ratios for the mill tailings samples are generally larger than those obtained for similar tissues at the LASL study site. This is best reflected by compositing all tissues to determine the CR, with the mill tailings ratio being about 4 times larger than the LASL ratio. The mill tailings ratio was slightly greater than 1, with the LASL ratio calculated at $10^{-1}$. For individual tissue groupings at the mill tailings site, GI and pelts had the largest ratio, followed by kidney tissues at $10^{-1}$, and carcass, lung and liver ratios of $10^{-2}$. Use of the median tissue values generally lowered the observed $C R^{\prime} s$, however, they remained within the same order of magnitude. For LASL study site samples the only CR calculated to be greater than I was for GI samples using the mean concentrations. Use of the median GI value decreased the $C R$ by an order of magnitude to $10^{-1}$. Pelts also exhibited CR's of $10^{-1}$, with the remainder of the tissue groupings having ratios of $10^{-2}$ and $10^{-3}$. 
Table 7. Concentration ratios of uranium for the study areas.

Using Mean

$\left(\frac{\text { Tissue } U}{\text { Soil } U^{\mathrm{a}}}\right)$
Using Median

( $\left.\frac{\text { Tissue } U}{\text { Soil } U^{a}}\right)$

$\underline{\text { LASL }}$

GI

1.48

0.66

Pelt

0.38

0.26

Kidney

$1.2 \times 10^{-2}$

$1.4 \times 10^{-2}$

Carcass

$7.5 \times 10^{-3}$

$6.7 \times 10^{-3}$

Lung

$6.1 \times 10^{-3}$

$1.8 \times 10^{-2}$

Liver

$1.2 \times 10^{-2}$

$1.4 \times 10^{-2}$

All tissues

0.32

Mill Tailings

Pile

GI

$\begin{array}{ll}2.40 & 2.62 \\ 0.72 & 1.40 \\ 7.1 \times 10^{-2} & 0.45 \\ 6.9 \times 10^{-2} & 6.8 \times 10^{-2} \\ 6.3 \times 10^{-2} & 8.3 \times 10^{-2} \\ & 3.4 \times 10^{-2}\end{array}$

Al1 tissues

1.15

${ }^{a}$ Soil concentrations for the $0-5 \mathrm{~cm}$ depth were used for purposes of these calculations. 
The observed concentration ratio provides an evaluation or estimate of the amount of uranium that moves across physiological barriers under conditions of their passage through the blological system (Comar, 1972), at the time of observation. Pelt, GI and lung values reflect the availability of uranium from the external environment to these consumers. The data indicates ingestion to be the major mechanism of concern for both study areas. Kidney, carcass and liver ratios, are indicators of the metabolic assimilation of uranium. The LASL results indicate that only a small portion of ingested uranium is assimilated, CR's for kidney $U \div G I$ being $10^{-3}$, and that most of the uranium is excreted from the body. The mill tailings results, however, indicate a larger amount of uranium to be metabolically assimilated, in the order of $10^{-1}$, presumably as a result of the more soluble form of uranium at this site.

\section{SUMMARY AND CONCLUSIONS}

This study was conducted to evaluate the vioavailability of uranium to Peromyscus maniculatus, the white footed deer mouse, from two separate source terms. One study area was located within the boundaries of the Los Alamos Scientific Laboratory (LASL) in north central New Mexico, at a dynamic weapons testing site where an estimated $70,000 \mathrm{~kg}$ of uranium have been expended. The second study area was an inactive uranium mill tailings pile located in west central New Mexico near Grants, generated from the milling of $2.7 \times 10^{9} \mathrm{~kg}$ of uranium ore. The objective of the study was to determine if the source term and resultant dispersal and distribution patterns in soil, affected the availability of uranium to Peromyscus.

Highest uranium concentrations in soils from the LASL study area were found within $10 \mathrm{~m}$ of the shot detonation site, averaging 4750 and $4910 \mu \mathrm{gU} / \mathrm{g}$ soil at 0 and $10 \mathrm{~m}$ distances, respectively. Surface soil 
uranium concentrations generally decreased exponentially with distance from the detonation point out to the farthest sampling locations of $200 \mathrm{~m}$. Samples taken at $5-$ to $10-\mathrm{cm}$ below the surface for sampling locations close in to the detonation site were only slightly lower than surface values. For sampling locations $20 \mathrm{~m}$ and beyond, results were highly variable, with lower horizon soils ranging from factors of 2 to 18 times lower than surface values. The uranium distribution in six soil size separates for both depth increments gave the following results: at a distance of $10 \mathrm{~m}$, the $<53 \mathrm{\mu m}$ size fraction had the highest concentrations; at $20 \mathrm{~m}$ to $50 \mathrm{~m}$ distances, highest concentrations were found for particles 1-2 $\mathrm{mm}$ in size; and for sampling locations at distances of $100 \mathrm{~m}$ to $200 \mathrm{~m}$, highest concentrations were associated with particles less than $500 \mu \mathrm{m}$ in size. High variation in uranium distributions, indicated a strong influence of uranfum dispersal patterns from the explosive test shots.

Soils from the perimeter of the uranium mill tailings pile had mean uranium concentrations about 50 times lower than the highest concentrations in LASL soils. Highest mean concentrations were detected on the east side of the pile averaging $86 \mu \mathrm{gU} / \mathrm{g}$ for the top $5 \mathrm{~cm}$ and $103 \mathrm{\mu gU} / \mathrm{g}$ for the 5- to $10-\mathrm{cm}$ depth. Over $90 \%$ of the soil mass and about the same percentage of the uranium inventory at this site were associated with particles less than $500 \mu \mathrm{m}$ in size. The reiatively homogeneous distribution of uranium in soils of this site were attributed to: the solubility of uranium at this site resulting from the refining process; and, the uniformity of soil particle sizes which optimizes vertical and horizontal soil mixing processes.

Uranium concentrations were generally higher in all small mammal tissue groupings for the LASL site when compared to values obtained 
for tissue sanples from the mill tailings study area. Concentrations of uranium in tissue samples were found not to be normally distributed about the mean and the distribution of values in tissue samples which had the highest concentrations were positively skewed. Nonparametric statistical testing showed that GI and pelt sample uranium concentrations were significantly different from internal tissue values for both sites. Perhaps one of the more significant findings of this study was that median uranium concentrations in kidneys of mice from the mill tailings study area were 6 times greater and significantly different from values for other internal tissues. This observation was not detected for the LASL study area. Low uranium values detected in lung tissues for both study sites indicated that inhalation of respirable size particle was not occurring appreciably during the sampling period, and that the major route for contamination was via ingestion.

Observed concentration ratios (CR) of animal tissue uranium to soil uranium ( $\mu \mathrm{gU} / \mathrm{g}$ ) for all tissue groupings composited were larger for mill tailings samples $(C R>1)$ than for LASL samples (CR 10 $0^{-1}$ ). The observed concentration ratio was used to provide an estimate of the amount of uranium moving across physiological barriers under conditions of their passage through the biological system. The LASL results indicated that only a small portion of ingested uranium was metabolically assimilated. However, the mill tailings results indicated a larger amount of ingested uranium to be metabolically assimilated and is attributable to a more soluble form of uranium at this site. 


\section{LITERATURE CITED}

Anderson, J.B., E.C. Tsivoglou and S.D. Shearer. 1963. Effects of uranium mill wastes on biological fauna of the Animas River (ColoradoNew Mexico). Pages 373-383 in Radioecology, V. Schultz and A.W. Klement, Jr., eds. Reinhold, NY.

Brandt, D.H. 1962. Measures of the movements and population densities of small rodents," Univ. Calif. Pub1. Zool. 62: 105-184.

Calhoun, J.B., Ed. 1948. North American census of small mammals, National Institutes of Health, Bethesda, Maryland.

Cannon, H.L. 1952. The effect of uranium-vanadium deposits on the vegetation of the Colorado Plateau, Am. J. Sci. 250: 735-770.

Comar, C.L. 1965. Movement of fallout radionuclides through the biosphere and man. Pages 127-158 in Ecological Aspects of the Nuclear Age:Selected Readings in Radiation Ecology, V. Schultz and F.W. Whi-..er, eds., TID-25978.

Cullen, T.L. and E.P. Franca, eds. 1977. International Symposium on Areas of High Natural Radioactivity. Academia Brasleira de Ciencias, Rio de Janeiro.

Dreesen, D.R. 1978. Uranium Mill Tailings, Environmental Implications. Los Alamos Scientific Laboratory Mini-Review LASL-77-37, 4 pp.

Gindler, J.E. 1973. Physical and Chemical Properties of Uranium. Pages 69-164 in Uranium-Plutonium Transplutonic Elements, H.C. Hodge, J.N. Stannard and J.B. Hursh, eds. (Springer-Verlag, NY).

Gladney, E.S., W.K. Hensley and M. Minor. 1978. A Comparison of Thr:? Techniques for the Measurement of Depleted Urarium in Soils. Anal. Chem., 50: $652-653$.

Hall, E.R. and K.R. Nelson. 1959. The Mammals of North America, Vols. $I$ and II (The Ronald Press Company, NY).

Hanson, W.C. 1974. Ecological considerations of depleted uranium munitions. Los Alamos Scientific Laboratory report LA-5559, 7 PP.

International Commission on Radiological Protection. 1960. Report of Committee II on Permissible Dose for Internal Radiation. Health Phys. $\underline{3}, 1$.

Johnson, L.J. 1972. Los Alamos land areas environmental radiation survey 1972. Los Alamos Scientific Laboratory report LA-5097-MS.

Koczy, F.F. 1963. The natural radioactive series in organic material. Pages 611-613 in Radioecology, V. Schultz and A.W. Klement, Ir., eds. Reinhold, NY.

Kovalsky, V.V., I.E. Vorotnitskaya, and V.S. Lekarev. 1967. Biogeochemical food chains of uranium in aquatic and terreneous organisms. Pages 329-332 in Radioecological Concentration Processes, B. Aberg and F.P. Hungate, eds., Pergamon Press, Oxford. 
Moslov, V.I., K.I. Maslova and I.N. Verklov Skaya. 1967. Characteristics of the radioecological groups of mammals and birds of biogeocoenoses with high natural radiation. Pages 561-571 in Radioecological Concentration Processes, B. Aberg and F.P. Hungate, eds., Pergamon Press, Oxford.

Mericle, L.W. and R.P. Mericle. 1965. Radiation and Terrestrial Ecosystems. Health Phys. 11, 1607-1620.

Miera, F.R., Jr., W.C. Hanson, E.S. Gladney and P. Jose. 1978. Mobili.. of elevated levels of uranium in the environment. In Proceedings of The Natural Radiation Environment III Symposium, W.M. Lowder and T.F. Gessell, eds. (In press).

Nyhan, J.W., L.W. Hacker, T.E. Calhoun and D.L. Young. 1978. Soli survey of Los Alamos County, New Mexico. Los Alamos Scientific Laboratory report IA-6779-MS, PP. 102.

Purtymur, W.D., C.L. Wienke and D.R. Dreesen. 1977. Geology and hydrology in the vicinity of the inactive uranium mill tailings pile, Ambrosia Lake, New Mexico. Los Alamos Scientific Laboratory report LA-6839-MS, $36 \mathrm{pp}$.

Snedecor, G.W. and W.G. Cochran. 1967. Statistical Methods. The Iowa State University Press.

Steinnes, E. 1971. Epithermal neutron activation analysis of geological material. Pages 113-128 in Activation Analysis in Geochemistry and Cosmochemistry, A.O. Brunfelt and E. Steinees, eds., Oslo, Universitets Forlaget.

Tsivoglou, E.C. and R.L. O'Connel. 1964. Nature, volume and activity of uranium mill wastes. In Radiological Health and Safety in Mining and Milling of Nuclear Materials, STI/PUB178. IAEA, Vienna

Voegtlin, C. and H.C. Hodge. 1953. Pharmacology and Toxicology of Uranium Compounds, Vols. III and IV (McGraws-H1ll, New York-TorontoLondon).

Yuile, C.L. 1973. Animal experiments. Pages 165-196 in Uranium-Plutonium Transplutonic Elements, H.C. Hodge, J.N. Stannerd and J.B. Hursh, Ed. (Springer-Verlaz, NY). 


\section{ACKNOWLEDGEMENTS}

The studies described in this thesis were made possible thru the assistance and facility support of the Environmental Science Group, Los Alamos Scientific Laboratory, Los Alamos, New Mexico. Although many individuals from this group contributed their time and efforts, the following are due special recognition: Tracy Schofield, John Booth, and Consuelo Montoya for sample collection and preparation; Ernie Gladney and Priscilla Johnson for uranium analysis of samples; and, Edna Montoya for typing of the manuscript.

I would also like to extend my gratitude to members of my Eiaduate committee, especially Dr. Anthony F. Gallegos and Dr. Shaun McEllin for their constructive criticism, continued support and patience over the past few years. Dr. Lora Shields, who will always remain a part of my memory and NMHU, and Dr. F. Ward Whicker, Colorado State University, must also be recognized, as this thesis and my career to date are to a large degree a result of thelr training, continued support and encouragement. 